\title{
Challenges in establishing and maintaining functional school libraries: Lessons from Limpopo Province, South Africa
}

Journal of Librarianship and Information Science

(C) The Author(s) 2016
Reprints and permissions:

sagepub.co.uk/journalsPermissions.nav DOI: I0.1 I77/096100061666780 I lis.sagepub.com

\&SAGE

\author{
Samuel Maredi Mojapelo \\ UNISA, South Africa
}

\begin{abstract}
Most governments, particularly in poor and developing African countries, are hesitant to pledge themselves through a legislated school library policy to roll out an active and sustainable library and information service for their schools to improve the quality of education. In South Africa, providing schools with a well-resourced and well-staffed library and information service is even more challenging because of the inheritance of the apartheid education system prior to 1994. The article is limited to just one part of a research project which investigated the resource provision in public high schools in Limpopo Province, South Africa. The purpose of the study was to investigate challenges that negatively affect the establishment and sustainability of an active and vigorous library and information service for all schools in Limpopo Province. The study was largely quantitative, blended with triangulation of both quantitative and qualitative methods for data collection. Self-administered questionnaires were used to collect quantitative data from the principals or teacher-librarians at schools, while an interview schedule was used to collect qualitative data from education officials through faceto-face interviews. The findings established that there are daunting challenges which hinder effective establishment and maintenance of functional school library and information service. The national Department of Basic Education has a responsibility to ensure that school library policy is formulated, endorsed and implemented as a matter of urgency. The Government should also fast-track rural development to enable teachers and learners, particularly those in historically disadvantaged rural black communities, to access library materials in other amenities.
\end{abstract}

\section{Keywords}

Limpopo Province, school libraries, school library funding, school library policy, South Africa

\section{Introduction and background to the study}

The significance of a legislated school library policy in championing, advocating and spearheading effective school library development initiatives world-wide cannot be overemphasised. However, most governments, particularly in poor and developing African countries, are hesitant to pledge themselves through a legislated school library policy to roll out an active, dynamic and sustainable library and information service (LIS) for their schools to improve the standard and quality of education. In South Africa, providing schools with a decent, standardised, well-resourced and well-staffed LIS is even more challenging because of the inheritance of the past apartheid education system prior to 1994 . Consequently, the schooling system is still characterised by rampant and massive disparities and inadequate resource provision which impacts negatively on teaching and learning accomplishments in schools.

Prinsloo (2002: 56) asserts that: 'The education challenge within South Africa is largely framed by the economic challenges facing the nation. The economic challenges are characterised most starkly by deep inequalities, high levels of poverty and unemployment and slow economic growth'. Thirteen years after this statement was published, nothing much has changed in this country. With

\footnotetext{
Corresponding author:

Samuel Maredi Mojapelo, UNISA, Box 392, Pretoria, Gauteng, 0003,

South Africa.

Email: mojapsm@unisa.ac.za
} 
high poverty levels particularly in historically disadvantaged and marginalised rural communities, economic challenges are the order of the day. In South Africa, the apartheid system calculatedly privileged whites at the expense of the other racial groupings (blacks, coloureds and Indians). Inequalities, poverty, unequal schooling, unemployment and slow economic growth are some of the circumstantial realities and challenges still affecting the country. In their study in KwaZulu-Natal, Du Toit and Stilwell (2012: 121) observe that:

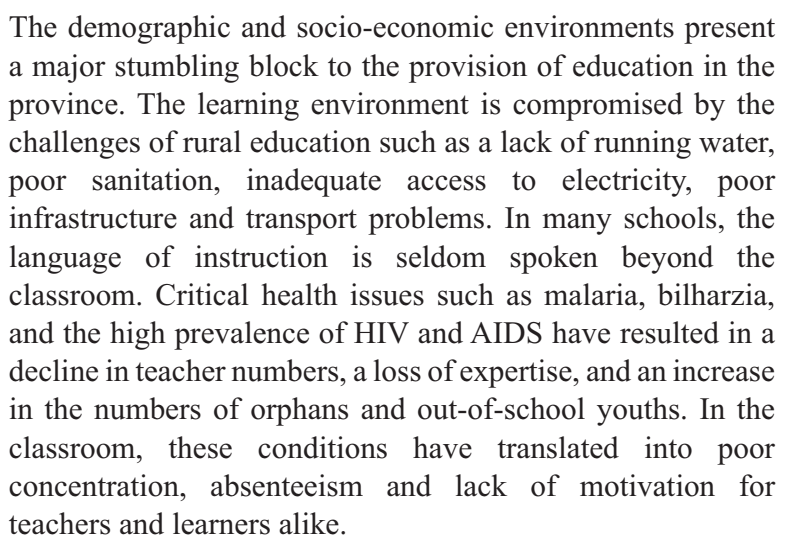

These are some of the contextual factors and challenges which hinder the provision of quality education in all South African schools and which directly or indirectly affect day-to-day teaching and learning endeavours in classrooms. Funmilayo (2013: 103-104) reiterates that 'the problem areas in the development of school libraries in Nigeria include lack of legislation, shortage of funds, poor accommodation, unavailability of trained staff, lack of relevant material and apathy on part of school administration and government' and Seroto (2011: 138) explains that: 'The challenges facing rural education in South Africa prior to 1994 were mainly shaped by political and economic factors, with state policies playing a role in ensuring that rural communities were marginalised and neglected'.

In South Arica, "the right to education has been achieved by making basic education compulsory, and the introduction of no-fee schools has gone a long way in achieving the goal of access to education for all' (Paton-Ash and Wilmot, 2013: 127). Subsequently, primary schools in particular are characterised by high learner enrolments to effect compulsory basic education. The Government's will to provide a quality education is evidenced by the increasing amount of funds allocated to the national Department of Basic Education. However, as observed by Hart and Zinn (2007) and cited by Paton-Ash and Wilmot (2013: 138) 'despite this increased expenditure, the inequalities due to past policy have not been addressed". Talk of the provision of quality education remains rhetorical in South Africa, particularly in poor and rural provinces such as Eastern Cape,
KwaZulu-Natal and Limpopo, because of inadequate and uneven allocation of a wide range of educational resources in schools (Motseke, 2005). Seroto (2011: 140) adds that:

[T]hree provinces in particular, namely the Eastern Cape, KwaZulu-Natal and Limpopo, are classified as predominantly rural as they have incorporated most of the former rural homelands. Homelands were predominantly populated by black South Africans, engaged in the production of crops and livestock mainly for own consumption or for sale on local, informal markets. Between 1960 and 1985, more than 3.5 million black people were forcibly relocated to homeland areas. It is in these three provinces where the majority of learners are found. Out of 12.3 million learners in 2009, two million are in the Eastern Cape, 2.8 million are in KwaZuluNatal and 1.8 million are in Limpopo. The remaining provinces have relatively lower learner enrolment. These three provinces are characterised by areas, which can only be accessed with difficulty because they are geographically isolated, and satisfy most of the criteria for rural education .... .

Because of a dire shortage of adequate classrooms for teaching and learning, most rural schools are not conducive to providing free basic education as desired by the post-apartheid government in South Africa. With dilapidated infrastructure in most schools, safety of the learners is highly compromised. There is a huge backlog in the provision of fixed classrooms in the majority of the schools across the country evidenced by the high number of mobile classrooms in most schools, particularly in historically disadvantaged and underprivileged rural communities, townships and informal settlements. In Eastern Cape, mud schools still feature in the province. In disadvantaged rural communities, because of inadequate water supply, sanitation is still a daunting challenge in most schools. According to the National Education Infrastructure Management System Standard reports (NEIMS, 2015), out of 3831 schools assessed in Limpopo, only 398 (10.3\%) have flush toilets while learners in 2537 (66.2\%) schools use pit toilets which pose risks to the learners' safety. The same trend is also apparent in rural provinces in South Africa, Eastern Cape and KwaZulu-Natal.

Turning to school libraries, Du Toit and Stilwell (2012: 120) note that:

Inequalities in school library provisioning under the former pre-1994 education departments resulted in widespread lack of facilities, inadequate resources, and a lack of trained personnel in the majority of schools. The disparities were further aggravated by the fact that there was no legislation forcing education departments to provide school libraries and establish library standards.

It is unacceptable that 22 years into the new political dispensation of 1994, resource provision for all schools has been neglected by the post-apartheid government. Even with the introduction of the learner-centred and 
resource-based education model in 1998, the allocation and distribution of wide-ranging library resources to all schools was a low priority. Du Toit and Stilwell (2012: 120) suggest that:

[T]he implementation of Curriculum 2005 in 1998 was seen as a turning point in South Africa's educational history in many ways and represented a new paradigm in education. It was anticipated that the outcomes-based curriculum with its concepts of integration and lifelong learning, as part of a new approach to education, would transform the legacy of the past and provide equal access to education for all learners.

Unfortunately, outcomes based education (OBE) failed dismally in South Africa, particularly in schools in historically disadvantaged and marginalised rural communities, townships and informal settlements (Motseke, 2005). The lack or inadequacy of library-based resources in most schools was observed as one of the swarm of contextual realities that contributed enormously towards its failure. Owing to the past apartheid inequality in terms of resource provision in all schools, the right to quality education was envisioned by the post-apartheid government. 'More recently, the Department of Basic Education acknowledged that quality of education was an urgent issue needing to be addressed' (Paton-Ash and Wilmot, 2013: 1270). However, the new government continued to neglect the provision of library-based resources to schools to guarantee quality education for all (Library and Information Services Transformation Charter, 2014). With 92\% of public schools without decent, well-stocked, well-staffed and sustainable school libraries in the country, it is rhetorical therefore to talk about the high quality of education in the majority of schools. 'As a result, school libraries cannot be referred to as transformation spaces in our educational landscape as there are simply not enough functioning libraries to make an impact' (Paton-Ash and Wilmot 2013: 136). Du Toit and Stilwell (2012: 120) reaffirm that: 'school libraries have thus far been largely ignored in education reform strategies and the onus is on provincial education departments to establish and develop school library services'. Without adequate funding for the procurement of resources and materials, provision of specialist librarian posts, infrastructure development and a legislated school library policy from the national Department of Basic Education, all school library developments and initiatives in the country are destined for failure. Consequently, the performance of most learners is negatively affected. In disadvantaged and marginalised rural communities, the situation is even worse. In South Africa, the government lacks the foresight to link learner achievement and provision of standardised, well-equipped and functional school libraries and their equitable collections. Lonsdale (2003) reiterates that well-resourced and well-staffed libraries can improve and boost learner performance in schools. With a majority of South African schools lacking well-equipped and functional school libraries, persistent low performance of South African learners in local and international tests is a testimony to their low literacy levels. Alongside international tests, it is incontestable that learners in South Africa are faring badly in Annual National Assessment (ANA) particularly in reading and numeracy. Silbert and Bitso (2015: 53) attest that: 'there remain deep inequalities in educational achievement in South Africa, particularly with regards to literacy and numeracy levels'.

Ideally, with well-resourced and functional school libraries, teachers and learners are provided with a plethora of educational resources such as print, visual, audiovisual and electronic information sources, including the Internet, to enhance and boost the quality of education. The IFLA/UNESCO School Library Guidelines Draft (2015: 7) notes that:

The goal of all school libraries is to develop information literate students who are responsible and ethical participants in society. Information literate students are competent selfdirected learners who are aware of their information needs and actively engage in the world of ideas. They display confidence in their ability to solve problems and know how to locate relevant and reliable information. They are able to manage technology tools to access information and to communicate what they have learned. They are able to operate comfortably in situations where there are multiple answers or no answers. They hold high standards for their work and create quality products. Information literate students are flexible, able to adapt to change, and able to function both individually and in groups.

This implies that a plethora of wide-ranging educational resources is required in all schools to enable active learners to source information on their own in order to meet their information and curriculum needs (Evans, 2014). Acquisition and development of information literacy skills occur when learners are exposed to a wide variety of library and information resources. Funmilayo (2013: 103) adds that "the school library equips students with lifelong learning skills and develops the imagination thus enabling them to live as responsible citizens'. Unfortunately, this is not the case for the majority of learners in South Africa. In South Africa, due to lack of adequate resource provision in the majority of the schools, it is therefore not uncommon for most teachers and learners to lack necessary information literacy skills which are fundamental for independent study, leisure reading and life-long learning.

With progressive, constructivist, resource-based and learner-centred education models being implemented in South African schools, diverse library-based resources are essential for enhancing and boosting innovative teaching and learning platforms and styles as embodied in the resource-friendly curriculum (Department of Basic Education, 2012; Hart, 2014). While the so called former advantaged Model $\mathrm{C}$ schools in historically 
advantaged and privileged urban communities have decent, well-resourced and well-managed functional school libraries because they charge extra fees from mostly middle-class parents to procure extra resources, including library resources, it is exactly the opposite for the majority of public schools in historically disadvantaged and deprived rural communities, townships and informal settlements (Library and Information Services Transformation Charter 2014; Hart 2013; Motseke, 2005). In what Bloch (2009: 59) called 'secondary economy', schools, progressive and constructivist teaching and learning endeavours are negatively impacted, raising the question of the quality of education offered to the 'born frees' in post-apartheid South Africa (Hart, 2014). Without exposure to a plethora of library resources, it remains a daunting challenge for the majority of the teachers and learners to develop and acquire adequate information literacy and reading skills, which are prerequisites for literacy development, independent and life-long learning (IFLA/UNESCO School Library Guidelines, 2015; Machet and Pretorius, 2008; 2009). With the lack of resource provision in most schools in the country, low literacy levels are common. Bloch (2009) asserts that that low literacy levels of the learners in South Africa are a national disaster.

\section{Apartheid's effects on the schooling system and resource provision}

To get a glimpse of the grim effects of the apartheid education system and to understand inequality and the enormous disproportions and discrepancies in the schooling system and resource provision in South African schools today, it makes sense to focus on the past.

In 1948, before the dawn of the new political dispensation in 1994, the National Party in South Africa resorted to the system of ruling known as apartheid (separateness). With the apartheid ideology of separate development, whites, Indians, coloureds and blacks were segregated along racial lines (Thompson, 2014; Van Zyl, 2002, Worden 2000). As the government legitimately sanctioned the apartheid ideology, it was duly evident in all its manifestations affecting all walks and spheres of life. Diverse Acts were passed by the apartheid parliament to perpetuate, propel and sanction the apartheid laws and policies, which were oppressive particularly to the majority black people. Van Zyl (2002: 11) confirms that "many more laws were passed to entrench the apartheid ideology'. According to Worden (2000: 108), the Population Registration Act "enforced the classification of people into four racial categories: white, coloured, "Asiatic" (Indian) and "Native" (later "Bantu" or African)'. A host of factors were used to separate the South African population. Although skin colour or race was the key issue used for discrimination, other factors such as language, ethnicity, creed and gender were also used to identify and separate people. Equal Education (2011a: 1) notes that:

Apartheid was the racist system of government that existed in South Africa before 1994. It was a system of racial discrimination, which oppressed black people while privileging whites from 1948 until 1994. An important part of apartheid was to make sure that black, coloured and Indian children received inferior education. Schools were separated according to race. Learners who went to white schools were given a quality education but black, coloured and Indian students received a poor education under the Bantu Education system.

Quality education for all was never conceptualised by the racist National Party, consequently and directly affecting non-white learners in South Africa. There were 19 fragmented education departments in apartheid South Africa to cater for the different needs of the learners as stipulated and determined by the Nationalist Government (Hart and Zinn, 2007). The following Acts were sanctioned to drive, propel and maintain the apartheid education system in the country.

Prior to 1994, the education system in South Africa was premised on two factors, namely, 'segregation and inequality' (Unterhalter, 1991: 35). The Bantu Education Act (Act 47 of 1953) was instituted to legalise discrimination in education (apartheid education) (Van Zyl, 2002; Worden 2000). According to Unterhalter (1991: 35), 'Bantu education has been treated as an unchanging mechanism of white domination'. Under this Act, all schools designated to non-whites (coloureds, Indians and blacks) were subjected to the Bantu Education system (Giliomee and Schlemmer, 1989; Thompson, 2014). The Act legalised the government's introduction of Bantu or native schools specifically for black learners to offer racially offensive and inferior quality education. The Department of Bantu Education and later the Department of Education and Training were established specifically to administer and oversee Bantu schools designated for black learners (Van Zyl, 2002). With the Bantu Education Act (Act 47 of 1953), the Nationalist Government's main agenda was to provide black learners with inferior quality education 'to meet labour requirements of the white people' (Van Zyl, 2002: 12). Hart and Zinn (2007: 91) assert that with inferior quality education, black learners 'were destined to be unthinking cogs in the labour machine, in no need of libraries'. Dick (2002) as cited by Paton-Ash and Wilmot (2013: 136) reaffirms that the Act 'entrenched an inferior education for black South Africans under the apartheid Native Affairs Department', which lead to the 'purge or closure of many existing black school libraries'. According to Worden (2000: 108), the Bantu Education Act (Act 47 of 1953) 'also imposed a uniform curriculum which stressed separate "Bantu culture" and deliberately prepared students for little more than manual labour'. 
Table I. Apartheid government spending on racially segregated education.

\begin{tabular}{ll}
\hline Learners & Government spending \\
\hline White learner & RI2II \\
Indian learner & R77I \\
Coloured learner & R498 \\
Black learner & RI46 \\
\hline
\end{tabular}

Source: Equal Education 20I la: I.

Without dedicated teacher-librarians, it was difficult to keep black school libraries open because all teachers were involved in mainstream subject teaching with high workloads. With this move, black learners were disempowered educationally, destined to be servants of the masters. With poor, underprivileged and illiterate parents in the homelands, most learners were taught without learner textbooks which impacted negatively on individualised learning. Equal Education (2011a: 1) suggests that 'Bantu Education was meant to educate non-white students to become servants and manual labourers of white people'. To accomplish its agenda, the apartheid government expenditure on education favoured white learners at the expense of their black counterparts (Giliomee and Schlemmer, 1989; Paton-Ash and Wilmot, 2013). Equal Education (2011a: 1) confirms that there was racially segregated government spending on South African learners in 1982.

Table 1 confirms enormous inequalities per capita per annum expenditure in the apartheid government spending between learners of different racial groupings. Government expenditure on education disadvantaged black learners immensely resulting in under-resourced and informationpoor schools. With eight times more spending on white learners compared to black learners, their (white learners') schools had adequate classrooms for teaching and learning and well-equipped educational amenities such as libraries, halls, sport fields and laboratories to guarantee high quality education. On the other hand, impoverished black schools were without sufficient educational resources. With meagre school fees levied from poor and destitute parents 'working in the lowest-paid sectors of the economy', teaching and learning accomplishments were greatly affected in black schools (Unterhalter, 1991: 50). Without a wide variety of educational resources, the didactic situation in the classroom in most schools was not conducive to quality teaching and learning activities at all. High learner enrolments and few classrooms meant that congestion and overcrowding were the order of the day. Performance in black schools was disastrous with a lot of dropouts and high failure rates. With under-resourced schools, the acquisition, development and promotion of information literacy skills, which are the fundamentals for independent studies and life-long learning, were greatly affected.

As the education system was discriminatory, black parents in the various disadvantaged and impoverished rural communities of the homelands were responsible for the construction of their own school infrastructure (buildings). Thompson (2014: 190) notes that 'the state was not obliged to provide equal facilities for the subordinate races'. With insufficient classrooms, deprived black parents could not afford to build extra educational amenities such as libraries for reading and acquiring knowledge and laboratories for experimentation, self-discovery and inquiry and researchbased learning styles and strategies. This partly explained the low literacy levels and high failure rates of black learners during the apartheid education system in South Africa. Without inadequate funding from the government, as observed by Paton-Ash and Wilmot (2013: 136), 'this translated into serious inequalities in school infrastructure'. Hart (2014: 1) reaffirms that:

These infrastructural problems are reflected in the uneven quality of our schools' academic performance. Although it is no longer accurate to talk of 'white' schools, the disparities in quality between the historically white sector of schooling and the historically black sector in South Africa are still evident, as shown in the statistic that in 2007 two percent of white school leavers failed the matric examination compared with $39 \%$ of blacks.

The apartheid government persistently injected more funds into the white schools than their black counterparts. Twenty-two years (2016) into post-apartheid South Africa, as observed by Hart (2014), it is still difficult to try to overcome the inheritance of the past apartheid government. Hart (2014: 2) suggests that:

We are still struggling to overcome the heritage of apartheid
education in which per capita expenditure varied between R5
403 on 'white' schools and R1 053 on schools in the rural
Transkei 'homeland'. Despite allocating large shares of
national expenditure to schooling ( $20 \%$ in 2014), huge
backlogs in basic facilities still exist 20 years later. According
to the government's 2011 National Education Infrastructure
Management System (NEIMS), of the 24,793 schools public
schools in the country, over 10,000 still had pit toilets and
about 3,000 were without electricity and water.

The Reservation of Separate Amenities Act (Act 49 of 1953) legalised separate facilities, buildings and services for the different racial groupings (Kalley, 2000). To cite an example, there were separate public toilets for blacks and whites. The Act also outlawed learners of the different races from schooling together (Giliomee and Schlemmer, 1989; Worden 2000). Under this Act, blacks were also barred from accessing library-based resources in public or community libraries in former advantaged and privileged white communities, as they were reserved for whites only. In her book, Apartheid in South African Libraries: The Transvaal Experience (Kalley, 2000), the author clearly outlines the apartheid library resource provision and services in apartheid South Africa. Despite the virtual 
non-existence of school libraries, there were also no public libraries in disadvantaged rural villages and communities designated for blacks in the homelands. Illiteracy and low literacy levels were sky-rocketing in black communities due to lack of access to library and information resources in public libraries. Disadvantaged and marginalised black communities were information poor environments, which inhibited and restricted black learners from acquiring the reading, decoding and writing skills that are prerequisites for literacy development. Due to high poverty and illiteracy levels, most black parents could not afford to buy reading material such as books, newspapers and magazines for their children for home use.

The Group Areas Act (Act 41 of 1950) legalised racial zoning of lands (Ross, 2005; Thompson, 2014). Worden (2000: 108) asserts that: 'Residential segregation had existed in some parts of the country since the earlier part of the century, but the Group Areas Act (1950) extended the principle of separate racial residential areas on a comprehensive and compulsory basis'.

Under this Act, blacks were confined to the impoverished and underprivileged homelands and townships with all their contextual realities and circumstances. Influxcontrol regulations were in force to monitor and restrict human movements, particularly to keep blacks away from 'invading' the white territories. It was therefore obligatory for blacks in particular to carry passes (identity documents) to monitor and restrict their movements. With a plethora of resources including library resources, historically advantaged and privileged Model C schools in white suburbs were earmarked for white learners only for quality education. The National Library of South Africa (2015: 21) confirms that:

Before 1994, schools were divided according to race. White schools were provided with libraries and teacher-librarians. Black secondary schools that fell under the South African government had libraries but no library staff, while some black primary schools had classroom collections. Schools in the so-called homelands had no library provision whatsoever.

Even today (2016), most schools in former homelands are still under-resourced in terms of library resources.

\section{Current status of school libraries in South Africa}

In addition to enhancing and boosting the performance of the learners, well-resourced and well-staffed school libraries can contribute positively towards the realisation and attainment of the Millennium Development Goals (MDGs) in various countries worldwide as stipulated by the United Nations. Fombad and Jiyane (2015: 191) affirm that: 'The library and information sector is well placed to contribute towards the realisation of the MDGs, as libraries provide a critical support structure for education, economic development and poverty eradication'.

In South Africa, well-stocked and functional school libraries are indispensable for teachers and learners to also advance and realise the goals of National Development Plan (NDP). However, the current school library situation in South Africa is depressing, making it difficult for most teachers and learners in the country to realise the MDGs. Despite broken promises and dashed hopes from the national Department of Basic Education, there are some new school LIS developments (Hart, 2014). The amended South African School Act stipulates that each school in the country should have a library facility, media centre facility or library stocks (Department of Basic Education, 2013). The non-governmental organisation (NGO) Equal Education must be credited for fighting tirelessly with government over the Norms and Standards for school infrastructure. In 2009, Equal Education started campaigning for One School, One Library and One Teacher-Librarian (Equal Education, 2011b; Hart, 2014). Court battles between Equal Education and government were the order of the day. With the Norms and Standards Act currently in place, Equal Education's triumph is a milestone - the provision of library resources in all schools in the country.

The Act, unfortunately, makes no mention of staff and resources or materials. Equal Education (2011b) estimated that more than R12bn is required from government coffers to provide all public schools in South Africa with a well-stocked and well-staffed library. The amount includes funds for library infrastructure development, library materials, and training and employment of a fulltime librarian or administrator. Approaching this resourceprovision problem using an incremental model, the government will hopefully provide each school with a library facility. Currently, the status of school libraries is gloomy. Table 2 indicates the current status of school libraries in South Africa.

According to Equal Education (2011b), the Library and Information Services Transformation Charter (2014) and the National Education Infrastructure Management System (NEIMS) (2011), only 7\% of public schools in South Africa have well-equipped and functional school libraries. 'These are almost entirely situated in historically advantaged Model C schools, which are able to stock and staff these facilities through their own resources' (Equal Education, 2011b: 1). This is a gloomy and appalling situation taking into consideration the importance of functional school libraries in modern learner-centred education models and the information age generally. In Limpopo Province, the situation leaves much to be desired because only $2 \%$ of the public schools have a well-stocked and well-staffed library facility (NEIMS, 2011). With these staggering figures, a turnaround strategy is indeed needed to improve the status of school LIS in South Africa. 
Table 2. The current status of school libraries in South Africa.

\begin{tabular}{lll}
\hline Schools with no library space & $\begin{array}{l}\text { Schools with library space that is } \\
\text { reportedly not stocked }\end{array}$ & $\begin{array}{l}\text { Schools with library space that is } \\
\text { reportedly stocked }\end{array}$ \\
\hline $79.3 \%$ & $13.5 \%$ & $7.2 \%$ \\
\hline
\end{tabular}

Source: Machet and Tiemensma (2009: 64).

\section{Purpose of the study}

The purpose of the study was to investigate challenges that negatively impact the provision and sustainability of functional school LIS for teachers and learners in Limpopo Province, which should be supporting progressive and constructivist teaching and learning styles and strategies as required by the resource-based curriculum.

\section{Research methodology}

According to the Limpopo Department of Basic Education Annual Survey Update Master (2015a), there are 1428 registered public high schools in the five districts of the province. To obtain a sample size relative to the size of the wider population under study, a look-up table for sample sizes from different sized universes was used (Payne and Payne, 2004: 204), according to which if the target population comprises 1500 units of analysis, the sample should be 306. As the target population in this study was 1428 public high schools, a total of 306 public high schools in the province was targeted. Within the sampled schools, this study specifically targeted principals or teacher-librarians. As schools are located either in rural or urban communities, it was necessary to categorise them to ensure an inclusive and representative sample. Two sampling methods were therefore used, namely stratified and systematic random sampling.

First, the stratified sampling technique was applied (Keyton, 2011). Two lists of schools were created - a rural and an urban school list. The aim was to draw state high schools from various socioeconomic backgrounds to ensure an even spread of schools in both strata in the sample. Second, the systematic random sampling technique was applied to both rural and urban school sampling frames to ensure fair distribution and selection of schools in each stratum (Walliman, 2011). From the list of $1265(89 \%)$ rural schools, 254 were randomly chosen. From a total of 163 (11\%) urban schools, 52 were randomly selected. Selfadministered questionnaires with self-addressed envelopes were mailed to 306 schools (see Appendix 1). There was a response rate of $163(53.2 \%)$ schools - 118 rural and 45 urban schools. Other respondents in the study included three education officials of the School LIS from the provincial Department of Basic Education in Polokwane who were selected through purposive sampling. An interview schedule was used to conduct face-to-face interviews to obtain qualitative data (see Appendix 2).
The responses from each item on the self-administered questionnaires were coded. The SPSS software package was used to analyse the data from the self-administered questionnaires. The responses to the closed-ended questions were pre-coded and the responses to the open-ended questions were post-coded, that is, coding categories were compiled to classify the collected data after the selfadministered questionnaires had been completed (Babbie, 2010). Data from the interviews were also categorised.

Data were analysed using simple descriptive statistics. Importantly, statistical information was used to identify relationships, trends and patterns and to make comparisons.

\section{Respondents of the study}

For this study, data were collected from two sets of respondents. As already noted, the respondents of the study at school level comprised the principals or teacherlibrarians. Self-administered questionnaires were used to collect quantitative data from them. By virtue of their appointment, principals are representatives of the government and are also policy implementers at schools. In case principals were unable to complete self-administered questionnaires due to other commitments, the so called teacher-librarians were eligible to complete them as they are drivers of school libraries. The researcher also collected qualitative data from three education officials, two chief education specialists and the senior manager all attached to the School Library Unit of the Limpopo Department of Basic Education. Employed and paid by the provincial Department of Basic Education, their main function is to assist schools to set up functional school libraries in all schools in the province. They are supposed to run workshops related to school libraries. They are also supposed to visit and monitor library facilities and resources at schools.

\section{Presentation and discussion of findings}

The findings are presented into themes and discussed using related literature.

\section{Schools with a library facility}

The findings established that only $27 \%$ of the schools in the rural category had a library facility (see Table 3a). This 
Table 3. Existence of a library structure or facility in schools.

a. Rural schools.

\begin{tabular}{llcccr}
\hline & & Frequency & Percentage & Valid percentage & Cumulative percentage \\
\hline Valid & Yes & 32 & 27.1 & 27.1 & 27.1 \\
& No & 86 & 72.9 & 72.9 & 100.0 \\
& Total & 118 & 100.0 & 100.0 & \\
\hline
\end{tabular}

b. Urban schools.

\begin{tabular}{lllcrr}
\hline & & Frequency & Percentage & Valid percentage & Cumulative percentage \\
\hline Valid & Yes & 22 & 48.9 & 48.9 & 48.9 \\
& No & 23 & 51.1 & 51.1 & 100.0 \\
& Total & 45 & 100.0 & 100.0 & \\
\hline
\end{tabular}

implies that the majority (73\%) of the schools in rural communities had no library facility whatsoever. However, in the urban category, the researcher found that nearly half $(49 \%)$ of the schools had libraries (see Table $3 b)$. Cumulatively, out of 163 schools, it was encouraging to note that more than half $(54.33 \%)$ of the schools in the province had some sort of facility for library use. The amended South African Schools Act of 1996 stipulates that each school is supposed to have a library facility (Department of Basic Education 2013). Through this Act, the government's quest for provision of school libraries is recognised. If this call is heeded, hopefully, the number of schools with a library facility can increase exponentially. However, as observed by Hart (2014: 1), 'the road is littered with dashed hopes and broken promises'

\section{School library committees}

The study sought to determine whether or not elements from established library guidelines are implemented at schools to advocate and champion the provision of libraries. Although effective governance is considered indispensable for the effective functionality of the different school library facilities, as depicted in Table 4, out of 163, most (108 or $66 \%$ ) respondents indicated that their schools operate without a library committee. Without this committee, the functionality of school libraries is severely hampered. School LIS professionals such as Govender (2007) indicate the impact of this body for effective establishment and maintenance of an active, vibrant and functional school LIS. When asked whether or not schools have library committees, the education officials responded:

Currently, not all schools have a library committee. We, however, encourage all schools to have a library committee. Fortunately, the Non-Governmental Organisation (NGO), Room to Read, is assisting schools in Greater Sekhukhune District to establish a functional school library committee. (Education official A)
School library committees are important for effective functionality of school libraries. Only a few schools have library committees. However, Room to Read is assisting the department to establish library committees in Greater Sekhukhune district where mobile library project is piloted. (Education official B)

Only a few schools have a library committee. However, most schools have learning and teaching support materials committees which also cater for the information needs of the teachers and learners although funding can be a problem. Hopefully, the situation will improve because Room to Read is helping schools in Greater Sekhukhune to constitute library committees. (Education official C)

All education officials were hopeful that assistance offered by Room to Read will cascade to other districts of the province. However, they all agreed that funding can be a problem.

\section{School library policy}

The study sought to establish whether or not schools have a library policy. As indicated in Table 4, of 163 respondents, the majority (123 or $79 \%$ ) indicated that their schools do not have a library policy. This negatively impacts efforts to resuscitate functional school libraries in the province. Without the promotion of decent, standardised, well-resourced and functional libraries by the government, most schools do not realise the importance of having a library policy. The three education officials commented:

Currently, the department has no school library policy. We have only a draft. (Education official A)

There is no school library policy in the province, however, there is a discussion document. Inputs are needed from relevant stakeholders but lack of adequate funding delays everything. (Education official B)

We only have a discussion document. (Education official C) 
Table 4. School library guidelines.

\begin{tabular}{|c|c|c|c|c|c|c|c|}
\hline School library guidelines & Responses & $\begin{array}{l}\text { Number of } \\
\text { rural schools }\end{array}$ & $\%$ & $\begin{array}{l}\text { Number of } \\
\text { urban schools }\end{array}$ & $\%$ & $\begin{array}{l}\text { Cumulative } \\
\text { total }\end{array}$ & $\begin{array}{l}\text { Cumulative } \\
\%\end{array}$ \\
\hline \multirow[t]{3}{*}{ I. School library committee } & Yes & 38 & 32 & 16 & 36 & 54 & 33 \\
\hline & No & 79 & 67 & 29 & 25 & 108 & 66 \\
\hline & Do not know & I & I & I & I & 2 & I \\
\hline \multirow[t]{3}{*}{ 2. School library policy } & Yes & 28 & 24 & 10 & 22 & 38 & 23 \\
\hline & No & 89 & 75 & 34 & 75 & 123 & 75 \\
\hline & Do not know & I & I & I & 2 & 2 & I \\
\hline \multirow[t]{2}{*}{ 3. Staffing } & Yes & 9 & 8 & 7 & 16 & 16 & 10 \\
\hline & No & 109 & 92 & 38 & 84 & 147 & 90 \\
\hline \multirow[t]{3}{*}{ 4. Annual budget } & Yes & 30 & 25 & 17 & 38 & 47 & 29 \\
\hline & No & 84 & 7I & 26 & 58 & 110 & 67 \\
\hline & No response & 4 & 3 & 2 & 4 & 6 & 4 \\
\hline Number of respondents & & 118 & 100 & 45 & 100 & 163 & 100 \\
\hline
\end{tabular}

When asked if it is implemented, all education officials indicated that because it is not an official and legislated document, it is not yet implemented. However, education official A indicated that 'informal implementation takes place along newly launched guidelines'.

Although the National Guidelines for School Library and Information Services (2012) guideline document offers an array of useful ideas, suggestions, and five library models in establishing and maintaining functional school libraries, it lacks the essential authority, credibility and mandate to force schools and the minister of the national Department of Basic Education to roll out an active, vibrant and dynamic school LIS for all schools in the country. As noted by Hart (2013: 49), the matter of 'mere guidelines' is questionable. The Library and Information Services Transformation Charter (2014: 48) affirms that: 'The Department of Basic Education's National Guidelines for School Libraries published in 2012 are to be welcomed; but, as mere guidelines, they have had little impact'. A legislated school library policy is therefore indispensable to champion and advocate for vigorous school library developments in the country, especially in South Africa, torn apart by apartheid prior to 1994. Hart and Zinn (2007) state that building a functional school LIS on apartheid foundations is clearly very challenging.

\section{Staffing}

With efficient, knowledgeable and dedicated staff, libraries can function effectively. However, in Limpopo Province, the findings of this study establish that staffing of library facilities is not yet a priority in most public high schools. In South Africa, equipping school libraries with full-time library staff is a daunting challenge. Lack of specialist librarian posts in public schools in the country remains a stumbling block for effective development of well-functioning school libraries.
When respondents were asked to indicate whether or not schools have full-time teacher-libraries, out of 163, the majority (147 or $90 \%$ ) of the respondents revealed a lack of professionally qualified or trained full time (permanent) teacher-librarians to administer and manage effective and vigorous school libraries. However, they indicated that professionally qualified full time teacher-librarians are crucial to keep the library facilities open on a daily basis and to manage the resources centrally.

The non-existence of permanent teacher-librarians at many schools is confirmed by many professionals such as Stilwell (2009). Equal Education (2010) estimates that only $23 \%$ of South African school libraries have a fulltime teacher-librarian which implies that $77 \%$ of library facilities lack staff to administer library resources. Without dedicated full-time librarians, accessibility to the information resources for both teachers and learners remains a challenge. Shandu et al. (2014: 20) posit that 'the accessibility of the library is closely related to funding'. Without staffing, even purpose built central libraries remain white elephants.

Hart and Zinn (2007) contend that teacher-librarians have been retrenched in large numbers or have been asked to step into full time mainstream subject teaching. When asked whether or not schools were provided with full-time teacher-librarians, education officials responded as follows:

No public school in this province has a full-time teacherlibrarian due to lack of librarian posts. Currently, we use ordinary teachers who are also subject teachers. Most library facilities are closed most of the time because of lack of fulltime staff to manage them. (Education official A)

Lack of appointment of full-time teacher-librarians impedes all school library initiatives. Due to heavy workloads, most of so called teacher-librarians are unable to attend school library workshops. Turn-around strategy is needed, otherwise there is no hope. (Education official B) 
The provincial Department of Basic Education is not mandated to appoint librarian posts in schools. This has a negative impact on functionality of library facilities. Something drastic needs to be done. (Education official C)

All education officials blamed the lack of professionally qualified teacher-librarians on the closure in 1994/1995 of the Lebowa In-Service Training Centre in Limburg, where teachers were trained to qualify as teacher-librarians. They regarded this move as a blow to the province, as there is now no in-service training centre to equip teacher-librarians with basic and essential library and information skills.

When asked to indicate whether or not their teacherlibrarians had qualifications or training in information science, of the 163 respondents, only 12 (7\%) indicated that their teacher-librarians had qualifications. A minority of the schools have teacher-librarians with qualifications or training in librarianship, therefore.

The respondents who had stated that their teacherlibrarians had library and information science qualifications were asked to state their qualifications. Out of 12 , three $(25 \%)$ respondents intimated that they had obtained a teaching diploma from former colleges of education, which included a course in school librarianship. Five of the respondents indicated that they had obtained a Further Diploma in Education - Education Media and Library and Media Science certificates. The latter was obtained from the former Lebowa In-Service Training Centre (LITC) in Limburg. One of the respondents indicated that he or she had obtained a school library certificate from the former University of the North, which is now called University of Limpopo. Two of the respondents had a diploma or degree in Library and Information Science. One respondent did not answer.

\section{Annual budget}

Funding is a major stumbling block, which impedes all concerted efforts for the establishment, development and maintenance of functional school LIS in South Africa. The study sought to establish whether or not schools had an annual budget specifically to buy library resources. As depicted in Table 4, out of 163 respondents, $47(29 \%)$ cumulatively yielded positive results. However, most (110 or $67 \%$ ) respondents in both urban and rural school categories replied in the negative. They indicated that adequate funding was needed to erect proper library buildings to provide sufficient space for shelves, seating, and other furniture needed to accommodate resources such as filing cabinets, racks and periodical shelving. Six respondents did not reply. Fredericks (1995) states that a lack of additional funding means that schools cannot purchase new and up-to-date library resources and equipment. PatonAsh and Wilmot (2013: 135) argue school libraries need to have sufficient funding for qualified staff, resources, technologies and resources for learners 'to become critical thinkers as well as effective users of information in all formats and media'. Shandu et al. (2014: 15) assert that: 'Insufficient library material and out-dated and inappropriate information resources are often the result of the lack of financial resources allocated to schools, or when budget cuts are made'.

The lack of a budget for school libraries in South Africa is also confirmed by professionals such as Hart and Zinn (2007) when they note that the ring-fencing of the library budgets that existed before 1994 was abolished, leaving schools with no money to buy library materials. Zinn (2006) concurs with this viewpoint by stating that changes in the funding formulae for library resources means that such library funds are no longer ring-fenced, which makes it almost impossible to obtain such funds.

As already established, the national Department of Basic Education does not have a budget and that is the reason why most schools do not buy new library resources, which is evidenced by the old, unsuitable and obsolete library materials found in the majority of school library facilities.

When asked whether or not their schools have received core collections from the provincial Department of Basic Education, out of 163, 132 (81\%) respondents (principals or teacher-librarians) indicated that their schools did not get core materials to kick-start a collection. When asked whether schools raised funds to buy library-based resources, out of $163,135(83 \%)$ respondents indicated that they did not venture into fundraising for procurement of library materials. When asked whether schools have funding for procurement of library resources, education officials responded as follows:

Currently, the provincial Department of Basic Education has no budget to enable schools to buy library based resources. Library budget was discontinued in 2007/2008 financial year because of budget cuts. We are also unable to buy core materials to enable schools to kickstart a library collection. The priority is on the procurement of the learning and teaching support materials (LTSM) for new curriculum, Curriculum Assessment Policy Statements (CAPS). (Education official A)

There is no budget for school libraries. We therefore cannot buy current and up-to date library materials for schools. Before 2007/08 financial year, schools used to have a library budget. All schools used to get $10 \%$ of the allocated Norms and Standards Grant to buy library resources, but that was terminated in the 2007/08 financial year due to budget cuts. (Education official B)

There is no allocation for schools to buy library materials. Lack of budget also affects our unit because we are not able to run adequate library workshops for all schools in the province. Due to budget constraints, visiting and monitoring schools to check their library facilities is also a nightmare. (Education official C) 
Funding for school libraries is also a huge challenge in many countries. Mutungi et al. (2014) state that many schools in Kenya do not allocate adequate funds to school libraries, which is confirmed by Papazoglou and Semertzaki (2001) who point out that even school libraries in Greece suffer from this lack of funding.

When asked to indicate challenges they face in establishing and maintaining schools libraries, respondents raised the following issues or concerns.

\section{Library facilitators}

The lack and inadequacy of the library staff was not only evident in schools, but also in circuits, districts and at head office for the running of day-to-day matters pertaining to school libraries. However, it was established that there is one senior manager and two chief education specialists at head office to attend to library matters for all 3915 primary and high schools in the province (Department of Basic Education, 2015a). Noticeably, they do not visit schools or regularly run library workshops. This is the reason why the majority (129 or $79 \%)$ of the respondents indicated that workshops are not organised for them to attend. This hampered school library development initiatives because teacher-librarians did not regularly attend workshops to support them in performing their tasks. The majority of teacher-librarians were untrained and this indicates that more workshops should be conducted, not only to equip them with basic library and information skills to make library facilities functional, but also to develop them professionally. Du Toit and Stilwell (2012) identified the exclusion of school librarianship from teacher training curricula, which means the majority of the teacher-librarians lack essential skills to administer school libraries.

Dubazana and Hoskins (2011) point out that there is an inadequate allocation of library facilitators, given the number of schools in various districts of KwaZulu-Natal. Consequently, they lack the capacity to run more workshops for all teacher-librarians in the province. Limpopo was under national administration when the study was conducted, and the researcher was informed that four vacant deputy chief education specialist posts could not be filled because the department was experiencing administrative and financial problems and therefore everything seemed to be on hold until the situation was normalised. The researcher must point out that it was beyond the scope of this study to investigate the financial and administrative problems experienced by the department.

\section{Marketing of the school libraries}

According to the National Guidelines for School Library and Information Services (2012), marketing and advocacy campaigns should be conducted to make stakeholders aware of the importance of school libraries in education
(Department of Basic Education, 2012). However, the study established that school libraries are not marketed and therefore users are not aware of their significance in education. Some 10 or $6 \%$ of respondents placed the blame on the shoulders of the national Department of Basic Education for not taking school libraries seriously and not regarding them as an essential service. Making users aware of the value of school libraries in education is also a challenge in other African countries. Funmilayo (2013:104) asserts that: 'Insufficient awareness of the significance of libraries in educational settings constitutes challenges to Nigerian school libraries'.

\section{Access to other information services or amenities}

It is well documented by the LIS professionals that public or community libraries, multi-purpose centres, tele-centres and Internet cafes can augment and assist schools to provide adequate information resources for teaching and learning purposes. However, eight $(5 \%)$ respondents established that there is limited access to library materials in the majority of the public or community libraries and multi-purpose centres, mainly because of distance. The study established that most of these amenities were situated quite far from the majority of the schools. This is confirmed by professionals such as Witbooi (2007) who argue that public or community libraries in South Africa are following the tradition of their colonial master, Britain, by being unevenly distributed. Witbooi (2007) emphasises that access to libraries was initially aligned along racial lines in the 1950s and was a service available to white people in the cities and towns. Because of this inheritance of apartheid legislation, access to libraries is still a challenge because of geographical and economical barriers such as the distances to travel and the cost attached thereto. Dent (2006) confirms that the dire lack of public libraries in Uganda puts more pressure on school libraries there.

With few or no public or community libraries, teachers and learners from historically disadvantaged rural communities are at a disadvantage (Mojapelo, 2014). Due to apartheid spatial planning, the majority of public or community libraries are still found in historically advantaged urban communities, while in historically disadvantaged rural communities, they are few or virtually non-existent. The aim of the conditional grant by the Department of Arts and Culture (KPMG, 2006) is to rollout more public or community libraries particularly in historically disadvantaged, marginalised and underprivileged communities.

\section{Library period on the timetable}

The study established that generally schools do not schedule a library period on the timetable. Only one respondent (1\%) mentioned that library-based resources can be 
accessed and utilised optimally if there is a period on the timetable to enable all teachers and learners to take turns in visiting library facilities. A study by Adeoti-Adekeye (1997) confirms that a library period needs to be on the timetable to enable learners to receive instruction in library use (library orientation) by the librarian in the library. This was confirmed by Magara and Batambuze (2009) who report that, in Uganda, reading lessons are included on the school timetable. During this period, learners are obliged to go to the library for reading sessions.

It is likely that the absence of a library period on the timetable discourages the teacher-librarians from teaching learners library and information skills because they are busy with their own subject teaching. In addition, they cannot design programmes such as information literacy, reading, spelling and library programmes because there is no library period on the timetable. Hence learners are not encouraged to use different reading materials to acquire reading skills, habits and culture. This situation is not conducive to literacy development. Consequently, learners have poor writing, reading, and decoding skills because they are not forced to acquire those skills from an early age. In South Africa, most learners in Grade 12 are not performing as expected because they do not have the basic skills to utilise library materials optimally and independently. Having a library period on the timetable may enable teacher-librarians to design and offer information literacy skills and other programmes that can be of paramount importance when learners enter tertiary institutions.

\section{Private sector}

The study established that most private sector companies were not taking the initiative and did not support the establishment and development of functional school libraries. Only two $(1 \%)$ respondents indicated that their schools received donations of educational resources from private sector companies to establish a collection. Some respondents blamed private sector companies for not being proactive and not taking the lead in ensuring that libraries are operational at schools. Magara and Batambuze (2009) point out that in Uganda, private sector companies have intervened in school library development initiatives by donating storybooks, textbooks and furniture. They indicate the need for schools to strengthen these partnerships to ensure continuity.

\section{Inter-school competitions}

Only one (1\%) respondent raised the concern that schools do not compete with each other concerning library events. Inter-school competitions could encourage learners to use the library resources optimally to improve the acquisition of reading and literary skills. Magara and Batambuze
(2009) reveal that reading competitions are encouraged among learners in Uganda as a stepping-stone towards the acquisition of reading skills and inculcation of a reading culture. They state that parents support the competitions by contributing gifts or prizes for participating learners. The respondent was of the opinion that private companies need to be approached to donate library materials to the participating schools.

\section{Security}

Some 16 (or 10\%) respondents and the education officials pointed out that, alarmingly, security is still a major and notable challenge in most schools. Seemingly, most public schools do not have security guards to patrol, especially at night and therefore they are vandalised and property, including valuable educational resources such as computers and the accompanying technology, is stolen. Security concerns at schools were also raised by authors such as Mojapelo (2014), Moswela (2010) and Witbooi (2006).

Paton-Ash and Wilmot (2015: 4) avow that:

Security was an emergent issue, especially amongst the low/ no fee-paying schools. These schools had experienced theft of their computers on more than occasion, with the result that they did not have full-equipped computer laboratories. They simply did not have the resources to replace the stolen equipment. Security problems were not confined to low/no fee paying schools. Two of the fee-paying ex-Model $\mathrm{C}$ Johannesburg schools had problems with theft, but were better able to combat the problem by paying for extra security.

With only $8 \%$ of the schools categorised in quintile 5 in the province, it is apparent that most (92\%) schools in the 'second economy' are characterised by vandalism and burglary (Bloch, 2009: 59). With insufficient Norms and Standards grants, poor schools in no-fee paying quintiles (1-3) lack financial muscle for extra security in their schools (Department of Basic Education, 2015b).

\section{Infrastructural challenges}

The study established that there are daunting challenges related to infrastructure in this mostly rural province.

Physical facilities. Most respondents identified the lack of basic physical facilities (classrooms) needed for teaching and learning, let alone structures to accommodate librarybased resources. Given that the number of schools lacking library space to accommodate library resources is $51 \%$, it is evident that school library provisioning was not adequate. Although respondents indicated that it was essential that they received more funds to build library buildings, education officials indicated that there was no budget to cater for library-related issues in the province. The respondents concurred that this was the reason why the 
majority of the schools did not have a library provisioning facility or infrastructure. Due to acute shortage of standalone or purpose built central school libraries, out of 163 , most (113 or 69\%) respondents collectively indicated that their library facilities did not have sufficient space. This was the reason why the majority of them were congested and lacked seating accommodation to enable users to use the resources. However, it is noticeable that some urban schools have sufficient space in their library facilities than rural schools. Sufficient space is a dilemma particularly where library-based resources are accommodated in facilities such as staffrooms or offices, classrooms and storerooms. Du Toit and Stilwell (2012) affirm that space is a dilemma in most school libraries. Despite restricted sitting accommodation in most library facilities, overcrowding and congestion are issues which adversely affect utilisation of the available resources or materials - hence underutilisation of library resources in most schools.

Electricity. Electricity is still a challenge in some of the South African schools. Even in 2015, some schools are yet not connected to the electricity grid, thus teachers and learners in those schools are deprived of opportunities to photocopy articles from newspapers, magazines and journals to make teaching and learning stimulating and interesting (Mojapelo, 2014). In this study, out of 163 , only one $(1 \%)$ respondent indicated that there is lack of electricity at his or her school. This is confirmed by the NEIMS Standard reports (2015). However, electricity supply is still a huge challenge to some rural communities and informal settlements in South Africa. Du Toit and Stilwell (2012) confirm that there is also still inadequate access to electricity in KwaZulu-Natal schools. The NEIMS Standard reports (2015) reaffirm that out of 5861, 610 (10.4\%) schools are without electricity in KwaZulu-Natal. Out of 5461, some 244 (4.4\%) schools in Eastern Cape still operate without electricity. Electricity is needed to operate electronic and electrical equipment such as scanners, computers and photocopying machines (Chilimo, 2008; Mojapelo, 2014). As the electricity supply is not consistent in South Africa, other methods of power supply are inevitable. However, it must be noted that only rich schools in affluent communities can afford to install solar panels and generators because they are expensive even to maintain.

Telecommunications infrastructure. Telecommunications infrastructure is essential for effective telephone systems and Internet connectivity. However, few (10 or 6\%) respondents said they had Internet connectivity because of the poor telecommunications infrastructure in the province. The situation is exasperated by an unreliable conventional telephone system, especially in historically disadvantaged rural schools, and this makes conventional Internet connectivity impossible in the rural environment (Mojapelo, 2014). Wireless modems can be used to connect to the Internet; however, in historically disadvantaged rural communities or villages, Internet connectivity is not possible due to the lack of Global Positioning System (GPS) coverage. Cellphones can be used to access the Internet even if it is uncertain whether they can download large amounts of data. Poor telecommunications infrastructure in rural communities is confirmed as a problem for school libraries by Kwake et al. (2006).

Roads infrastructure. The road conditions in most of the historically disadvantaged communities are terrible, compounding transport problems. Most of the roads in the province are gravelly and dusty with bridges that are unstable, unreliable and not standardised, resulting in rapid flooding when it rains (Mojapelo, 2014). Education officials indicated that schools in these communities often cannot be reached when it rains heavily. Because of these poor road conditions, it is very difficult to introduce and implement mobile library services and courier services between schools and depot libraries. Terrible road conditions were also cited by authors such as Kwake et al. (2006) as hindrances in the use and availability of Information and Communication Technologies (ICTs) in rural areas of KwaZulu-Natal. While they indicated that 12.5\% of the roads in rural KwaZulu-Natal were poor, the situation in Limpopo, which is mainly rural, is terrible because $68 \%$ of the roads are dirt and gravel (Masoga, 2013).

Vastness of the province. Education officials commented that as the province is a merger of three former homelands or bantustans from the apartheid era, it is extremely large and mainly rural with many schools in historically disadvantaged, remote and rural communities. This means that sufficient funds are vital to develop infrastructure and to buy library-based resources for all these schools. This has considerable financial implications.

\section{Summary, conclusions and recommendations}

A wide variety of library and information resources is critical in schools world-wide to improve the standard and quality of education. However, owing to the legacy of apartheid, there are huge disparities and backlogs in resource-provision in South African schools. The schooling system is therefore still characterised by huge inequalities in resource-provisioning. Equal provision of wide-ranging information resources in all schools is not yet a priority for the new democratic government. Without a plethora of information resources to improve and enhance teaching and learning initiatives in all schools, it is questionable to talk about the quality of education in postapartheid South Africa. The study established that the provision and sustainability of decent, standardised, wellresourced and well-staffed school libraries in Limpopo is 
compounded by an array of challenges. Consequently, the majority of schools operate without functional school libraries compromising the quality of education to the 'born frees'.

With the exception of historically advantaged and privileged ex-Model $\mathrm{C}$ schools earmarked for white learners only under apartheid rule, 22 years into the post- apartheid era, most public schools still lack the necessary infrastructure, budget and staffing for provision and sustainability of proper, standardised, well-stocked and well-staffed school libraries. To redress and address the problem of resourceprovisioning in all schools, political will from the government through the Minister of the National Department of Basic Education is essential. While a legislated school library policy is not a guarantee that different school library facilities will function, the study recommends that its inherent value in championing and advancing wellresourced and functional school library services cannot be underemphasised. In the meantime, government should fast-track rural development to enable teachers and learners to access information in other information services or amenities such as public or community libraries, tele-centres, multipurpose centres and Internet cafes for their curriculum requirements. Roads and telecommunications infrastructure need to be improved to enhance access to information. With improved road conditions, mobile and courier services can also be introduced to bring teachers and learners closer to the information.

\section{Funding}

This research received no specific grant from any funding agency in the public, commercial, or not-for-profit sectors.

\section{Note}

1. For funding purposes, all public schools in South Africa have been categorised into five quintiles. The socio-economic conditions of communities in which schools are located are used to rank or classify them. 'The national poverty table, prepared by the Treasury, determines the poverty ranking of areas based on data from the national census including income levels, dependency ratios and literacy rates in the area. Provinces then rank schools from quintile 1 to 5 , according to the catchment area of the school. The poorest schools are included in quintile 1 and the least poor in quintile 5' (Hall and Giese, 2008/2009: 37).

\section{References}

Adeoti-Adekeye WB (1997) The need for user education in secondary school libraries. Library Review 46(8): 586-592.

Babbie E (2010) The Practice of Social Research.12th edn. Belmont, CA: Wadsworth.

Bloch G (2009) The Toxic Mix: What's Wrong with South Africa's Schools and How to Fix It. Cape Town: Tafelberg.

Chilimo WL (2008) Information and communication technologies and sustainable livelihoods: A case of selected rural areas of Tanzania. PhD Thesis, University of KwaZuluNatal, Pietermaritzburg, South Africa.

Department of Basic Education (2012) National Guidelines for School Library and Information Services. Pretoria: Department of Basic Education.

Department of Basic Education (2013) South African Schools Act, 1996 (84/1996). Regulations relating to minimum uniform norms and standards for public school infrastructure. Government Gazette 581(37081) 29 November 2013. Available at: www.education.gov.za/LinkClick. aspx?fileticket=eToljlh2zmo\%3D (accessed 10 September 2014).

Department of Basic Education (2015a) Annual Survey Update Master. Polokwane: Department of Basic Education.

Department of Basic Education (2015b) South African Schools Act, 1996 (84/1996). Amended national norms and standards for school funding. Government Gazette 17(38397) 16 January 2015. Available at: www.education.gov.za/ LinkClick.aspx?fileticket. ..tabid=188\&mid... (accessed 17 September 2015).

Dick A (2002) Five reasons why South African librarianship remains untransformed. Innovation 25: 27-36.

Dubazana K and Hoskins R (2011) Promoting equitable access to school libraries in KwaZulu-Natal: The role of the Education Library Information and Technology Services (ELITS). Innovation 42: 114-131.

Du Toit M and Stilwell C (2012) KwaZulu-Natal school library policy and its feasibility for implementation in the province. South African Journal of Libraries and Information Science 78(2): 120-131.

Equal Education (2010) We Can't Afford not to: Costing the Provision of Functional School Libraries in South African Public Schools. Elonwabeni, Cape Town: Equal Education.

Equal Education (2011a) Unequal Schools, Unequal Outcomes. Available at: www.equaleducation.org.za/.../2011-08-17Fact-Sheet-1_Unequal-Scho... (accessed 13 June 2015).

Equal Education (2011b) We Can't Afford not to: Costing the Provision of Functional School Libraries in South African Public Schools. Elonwabeni, Cape Town: Equal Education.

Evans DL (2014) Training teacher-librarians to establish and manage school libraries in KwaZulu-Natal: An empirical study. Mousaion 32(2): 106-123.

Fombad M and Jiyane GV (2015) School libraries in South Africa and the Post-2015 Millennium Development Goals (MDGs). Libri 65(3): 191-205.

Funmilayo DC (2013) Issues and options in selected secondary school libraries in Akure south local government area of Ondo State, Nigeria. Journal of Education and Practice 4(12): 103-110.

Giliomee H and Schlemmer L (1989) From Apartheid to Nation Building: Contemporary South African Debates. Cape Town: Oxford University Press.

Govender R (2007) The role of the school library committee in governance: Case studies of three public schools in KwaZulu-Natal. MEd Thesis, University of KwaZuluNatal, Durban, South Africa.

Hall K and Giese S (2008/2009) Addressing quality through school fees and school funding. South African Child Gauge 2008/2009: 35-40. 
Hart G (2013) How school libraries improve literacy: Some evidence from the trenches. Mousaion 31(1): 47-60.

Hart G (2014) Converging paths in the drive for school libraries in democratic South Africa. In: IFLA world library and information conference, IFLA 2014, Lyon, France, 16-22 August 2014. Available at: http://library.ifla.org/991/1/213hart-en.pdf (accessed 24 August 2016).

Hart G and Zinn S (2007) The conundrum of school libraries in South Africa. In: Bothma T, Underwood P and Ngulube P (eds) Libraries for the Future: Progress and Development of South African Libraries. Pretoria: Library and Information Association of South Africa, pp. 89-107.

IFLA/UNESCO (2015) School Library Guidelines Draft. 2nd edn. Unpublished draft document. IFLA/UNESCO. Available at: www.ifla.org/files/.../school-libraries.../ ifla-school-library-guidelines.pdf (accessed 10 October 2015).

Kalley JA (2000) Apartheid in South African Libraries: The Transvaal Experience. Lanham, MD: Scarecrow Press.

Keyton J (2011) Communication Research Asking Questions, Finding Answers. 4th edn. Boston, MA: McGraw Hill.

KPMG Department of Arts and Culture (2006) Status Quo Report. Available at: ca/files/SOFILibrary08Final.pdf (accessed 1 May 2010).

Kwake A, Ocholla DN and Adigun MO (2006) The feasibility of ICT diffusion and use amongst rural women in South Africa. South African Journal of Libraries and Information Science 72(2): 108-118.

Library and Information Services Transformation Charter (2014) 7th edn. Commissioned by the Department of Arts and Culture (DAC) and National Council for Library and Information Services (NCLIS). Available at: http://www. nlsa.ac.za/Downloads_01/2014_Final_LIS_Transformation_ Charter.pdf (accessed 9 September 2016).

Lonsdale M (2003) Impact of School Libraries on Student Achievement: A Review of the Research. Camberwell, Victoria: Australian Council for Educational Research.

Machet MP and Pretorius EJ (2008) The impact of storybook reading on emergent literacy: Evidence from poor rural areas in KwaZulu-Natal, South Africa. Mousaion 26(2): 261-289.

Machet MP and Tiemensma L (2009) The literacy environment in support of voluntary reading: A case study in Gauteng East and the Highveld Ridge Area. M. Inf thesis, Pretoria: University of South Africa.

Magara E and Batambuze C (2009) Reading promotion programmes in primary schools: A study of school library management practices in Pallisa District in Uganda. Mousaion 27(Special Issue): 108-127.

Masoga L (2013) Polokwane 2030 Smart Transport Vision. Speech by the Honourable MEC for Roads and Transport Lehlogonolo Masoga, Member of the Provincial Legislature, during the official launch of the Polokwane 2030 Smart Transport Vision at the Ngoako Ramatlhodi Indoor Sports Centre. Available at: www.gov.za/speech-honourable-mecroads-and-transport-lehlogonolo-... (accessed 15 March 2015).

Mojapelo MS (2014) Provision of school libraries in public high schools in Limpopo Province, South Africa. PHD Thesis, University of South Africa, Pretoria.
Moswela B (2010) Book security in senior secondary schools in Botswana: An imperative to quality education.SA-eDUC Journal 7(1): 16-25.

Motseke MJ (2005) OBE: Implementation problems in the black townships of South Africa. Interim: Interdisciplinary Journal 4(2): 113-121.

Mutungi B, Minishi-Majanja M and Mnkeni-Saurombe N (2014) The status of school libraries in Kenya: The case of public secondary schools in Nairobi County. Mousaion 32(2): 150-172.

National Education Infrastructure Management System (NEIMS) (2011) National Assessment Report (Public Ordinary Schools). Contract EDO305. Available at: www.education. gov.za/LinkClick.aspx?filetickettabid $=358$ (accessed 10 October 2012).

National Education Infrastructure Management System (NEIMS) (2015) National Assessment Report (Public Ordinary Schools). Contract EDO305. Available at: www.education.gov.za/LinkClick.aspx? fileticket...tabid=358\&mid (accessed 15 January 2015).

National Library of South Africa (2015) The State of Libraries in South Africa. IFLA edn. Pretoria: The National Library of South Africa.

Papazoglou A and Semertzaki E (2001) Changes and developments in Greek libraries. The Electronic Library 19(3): 158-167.

Paton-Ash M and Wilmot D (2013) The state of school libraries in South Africa. Journal of Education 57: 127-162.

Paton-Ash M and Wilmot D (2015) Issues and challenges facing school libraries in selected primary schools in Gauteng Province, South Africa. South African Journal of Education 35(1): 1-10.

Payne G and Payne J (2004) Key Concepts in Social Research. London: SAGE.

Prinsloo E (2002) Challenges in the provision of schooling in South Africa: In: Van Wyk N and Lemmer EM (eds) Transforming Education: The South African Experience. Hauppauge, NY: Nova Science, pp. 49-76.

Ross R (2005) A Concise History of South Africa. Cambridge: Cambridge University Press.

Seroto J (2011) The provision of rural education in three provinces of South Africa since 1994: Implications for social improvement. Journal of Education Studies (Special Issue Social Justice): $138-152$.

Shandu L, Evans L and Mostert J (2014) Challenges in the provision of school library services in Katlehong secondary schools. Mousaion 32(4): 13-28.

Silbert P and Bitso C (2015) Towards functional school libraries: Supporting library assistants in under-resourced schools through a university-community-school partnership. South African Journal of Libraries and Information Science 81(1): 53-62.

Stilwell C (2009) Mapping the fit: Library and information services and the national transformation agenda in South Africa, Part II. South African Journal of Libraries and Information Science 75(1): 1-11.

Thompson L (2014) A History of South Africa. 4th edn. New Haven and London: Yale University Press.

Unterhalter E (1991) Changing aspects of reformism in Bantu education 1953-89. In Unterhalter E, et al. (eds) Apartheid Education and Popular Struggles. Johannesburg: Ravan Press, pp. 35-72. 
Van Zyl AE (2002) South Africa: The country and the development of education. In: Van Wyk $\mathrm{N}$ and Lemmer EM (eds) Transforming Education: The South African Experience. Hauppauge, NY: Nova Science, pp. 1-21.

Walliman N (2011) Research Methods: The Basics. New York: Routledge Taylor and Francis.

Witbooi SL (2006) Setting up a joint-use library facility: Testing an African model in Wesbank Western Cape. Innovation 32: $42-54$.

Witbooi SL (2007)Current developments in public libraries in South Africa, In: Bothma TJD, Underwood P and Ngulube P (eds) Libraries for the Future: Progress and Development of South African Libraries. Pretoria: LIASA, pp. 61-70. Available at: http://www.dissanet.com/jsp/ifla/book.jsp (accessed 25 April 2011).

Worden N (2000) The Making of Modern South Africa: Conquest, Segregation and Apartheid. 3rd edn. Malden, MA: Blackwell.
Zinn S (2006) Have trained school librarians made a difference for school libraries in South Africa. Innovation 33: $21-35$.

\section{Author biography}

Maredi Samuel Mojapelo is a Lecturer in the Department of Information Science, University of South Africa (UNISA). He worked as a Teacher in Limpopo Province for 22 years. After that, he joined the Gauteng Department of Basic Education in 2008 as a Senior Education Specialist: Library Services. He also served as a member of the Limpopo Province Library and Information Services Board for two terms. His main areas of interest at present are school and public or community libraries, collaborations and partnerships (ecosystems) in LIS and ICTs in education. He completed his $\mathrm{PhD}$ in Information Science at Unisa in 2015.

\section{Appendix I}

Questionnaire 1: For completion by the principals or teacher-librarians.

Kindly assist the researcher by completing this questionnaire. Do not write your name as all answers or responses will be treated as confidential.

\section{INSTRUCTION:}

Please indicate your responses or answers to each question by making a cross $(\mathrm{X})$ in the appropriate block(s) or writing in the spaces provided.

\section{SECTION A (SCHOOL LIBRARY GUIDELINES)}

1. Does your school have a library?

\section{YES}

NO

2. Does your school have a School Library Committee?

$\square \quad \mathrm{YES}$

$\square \quad \mathrm{NO}$

$\square$ DO NOT KNOW

3. Does your school have a school library policy?

YES

NO

DO NOT KNOW

4. Is the library managed by a full time teacher-librarian? (Mark one block only)

$\square$ YES

$\square$ NO

5. Does the librarian have qualifications in Library and Information Science?

(Mark one block only)

$\square \quad$ YES

$\square \mathrm{NO}$

6. If your answer to question 2 is YES, state the qualifications.

(Specify in the spaces provided) 
7. Does your school have an annual budget specifically to buy library-based resources? (Mark one block only)

YES

NO

DO NOT KNOW

8. Does your school fundraise to buy library resources?

YES

NO

DO NOT KNOW

\section{SECTION B (CHALLENGES)}

In your opinion, what are the challenges that the schools are facing in establishing and maintaining functional school libraries? Explain briefly.

(Use spaces provided)

\section{Appendix 2}

Interview schedule for education specialists: School Library and Information Services UNIT

SECTION A: (SCHOOL LIBRARY GUIDELINES)

1. Does the Department of Basic Education in Limpopo Province have a school library policy?

YES or NO?

2. If the answer is YES, is it implemented? Explain briefly.

3. If the answer is $\mathrm{NO}$, why?

4. Do schools have a School Library Committee? YES or NO

5. Does the Department of Basic Education provide for full time teacher-librarians in schools?

6. Does the Department of Education supply schools with a core collection to kickstart a school library collection? Explain briefly.

7. Do schools get funding from the Department of Basic Education specifically to buy library-based resources? Explain briefly.

\section{SECTION B: (CHALLENGES)}

In your opinion, what are the challenges that the Department of Education is facing in establishing and maintaining functional school libraries? Explain briefly. 